\title{
Morals Coaching Through Tahfizh al-Quran in Islamic Junior High School: A Case Study in PERSIS Islamic Boarding School in Karangpawitan Garut West Jawa
}

\author{
Laena Zakiyah ${ }^{1}$ \\ ${ }_{1}^{1}$ Postgraduate Program State Islamic University Sunan Gunung Djati Bandung, Indonesia \\ Email: laenazakiyah@yahoo.co.id
}

\begin{abstract}
:
Porn video cases involved to Islamic junior high school and college students which are the umpteenth of juvenile delinquency in any cases. The above case is certainly influenced by any cases that very concern and also shows the loss of moral education in the education world. The Ministry of Religion and the Ministry of National Education have essentially concerned to improving educational system in Indonesia. It is to lead the formation of moral and religious spiritual that is still seemed very minimal. The aim of this study is to answer the question on what is the expected of learning moral in the purposive line of educational activities through the development of student personality. This paper requires a new concept in reconstructing the concept of formal education today to lead the formation of character or morals, and its implication to the improvement of spiritualreligious values among the students. In the case of MTs Karangpawitan Garut, Islamic Union is seeking to maximize the interaction between cognitive and psychomotor aspects in the whole of education process. Unfortunately, much of them are still trying to internalize the values of the Qur'an as God's revelation to be applied in behavior or morals. Based on the background, this study shows that morals coaching through tahfizh al-quran in Islamic Junior High School can be seen one of the learning model to rebuilding the student character.
\end{abstract}

Keywords: Moral, Coaching, Education, Learning, Improvement, Cognitive, Psychomotor.

\section{A. INTRODUCTION}

It has become an imperative for educators to inculcate Islamic values in an effort to filter external values of Islam, so that learners are able to direct yourself on positive things and not drift to the struggle of values (War of Values). They themselves must come to organize, foster, develop and take control of the values developed in the community. Therefore, the expertise of the most major and important for educators to understand and able to assume the mission in developing the personality intact by way of foster care that learners have the courage or the commitment to hold the values of teaching is the source of human life guidance.

Educational experts give different understanding of education, there are shows similarities and differences also exist. The author cites some education experts as below:

Tafsir (1994: 26) to give an opinion that: 
"Education is a personal development in all its aspects, with the explanation that what is meant is the personal development is education that includes education by themselves, by environmental education and education by others (teachers), covering all aspects of body, mind and heart". According to Tafsir (2008: 46) that education should be able to educate people to be human. The purpose of education is to increase the degree of humanity. Actual human beings who have a high degree of humanity that is what can be called human.

While understanding of education according to Mohamad Natsir (1954: 87) is a physical and spiritual leadership to perfection completeness sense of humanity with real meaning. According to the Law on National Education System (Education) Chapter 1, Section 1, "Education is a conscious and deliberate effort to create an atmosphere of learning and the learning process so that learners are actively developing the potential for him to have the spiritual power of religion, self-control, as well as the skills needed him, society, nation and country". (Education Law No. 20 th., 2003).

According to Qaradawi (1980: 157) gives the sense of Islamic education that is "Whole person education, intellect and heart, spiritual and physical, character and skill. Because Islamic education to prepare people to live and prepare to confront the public with all the goodness and wickedness, sweet bitterness". Similarly conveyed Ansari (1976: 85) that Islamic education is a process of guidance (leadership, guidance, suggestions) by students' object to the development of the soul (thoughts, feelings, wishes, intuition, and so on).

According to Al-Syaebani in Arifin (2009: 15) that education is defined as "an attempt to change the behavior of individuals in their personal lives or society life and life in the natural surroundings through the educational process.

Clearly, when referring to the above opinion that the education process is an attempt to guide, direct the potential of human life in the form of basic skills and learning ability, so there was a change in his personal life as being individual and social development and in conjunction with the natural surroundings in which he lives. The process is always in Islamic values, the values that gave birth to religious norms and al- akhlāq al-karīmah.

"Every child is born in a state of purity, then both parents make them Jewish, Christian, or Zoroaster". (H.R: Bukhari and Muslim).

Hadiths the Prophet Muhammad SAW above shows that in the process of education someone very close will affect the character and nature of a child. Thus, the family, the community will have an impact on the child. The development of the individual personality is influenced by various factors including heredity and environment. Hereditary conditions that affect other antra personality; body shape, body fluids, and the properties inherited from parents. The environmental factors include the home environment, school and community. In addition, although a person's personality is relatively constant, the reality is often found changes in personality. Changes that occur are influenced by environmental factors and physical disorders. (Joseph et al. (2008: 19).

In the formulation of Islamic Education Seminar in Indonesia in 1960, gives the sense that Islam education "as guidance toward the spiritual and physical growth according to the teachings of Islam with wisdom to direct, teach, train, nurture and oversee the enactment of sumua teachings of Islam". The term guiding, directing, nurture, teach or train implies trying to influence the soul of the students through the process level by level to the goals set, which is "to instill piety and morals and to uphold the truth, forming a human is impersonal and virtuous according to the teachings of Islam". Likewise, in the Congress of the World II on Islamic education, through seminars on Conception and 
Curriculum of Islamic Education, 1980 stated that: "Islamic education is intended to achieve balanced growth of the human person as a whole through mental exercises, reasoning, keceradasan, feelings and senses. Therefore, Islamic education should develop mansuia all aspects of life, whether spiritual, intellectual, imagination, physical, keilmiahannya, the language both individually and in groups, as well as encouraging aspects of it toward goodness and toward attaining the perfection of life".

While Al-Jamaly in Arifin (2009: 18) says that "education is the process that leads people to the good life and the uplifting of humanity in accordance with the basic capabilities (nature) and the ability ajarnya (outside influence)".

The above opinion is based on the word of Allah in the letter of Ar-Rum verse 30 and An-Nahl verse 78 as follows: This means: (still above) the nature of God has created man in the fitrah (Q.S. ArRum: 30). The right education is that provides the opportunity for openness to outside influences and the development of the students. Thus, the nature then it is given the right to form the individual child and at the same time external factors will educate and direct the basic capabilities (nature) of the children. Therefore, education is operationally containing two aspects, namely maintaining or improving and growing aspect or fostering. Religion plays an important role in the life of mankind. Religion as a guide in creating a meaningful life, peace and dignity. Recognizing the importance of the role of religion in human life it is the internalization of religious values in the life of each individual becomes a necessity, taken through a good educational environment education in families, schools and communities.

Some understanding of education put forward by some of the education experts, the importance of religious education intended to enhance the spiritual potential and shaping students to become a man of faith and piety to Allah and noble. Noble character regarding ethics, manners, and morals as a manifestation of religious education. Increased spiritual potential include the recognition, understanding, and cultivation of religious values and practice these values in individual or collective social life. Increased spiritual potential that ultimately aims at optimizing the potential of the various human actualization reflects the status and dignity as a creature that is noble.After understanding the concept of education and Islam, then the next the author cites several opinions that blends these two concepts, namely the educational concept of Islamic Religion of some education experts including the following: International Conference on Islamic Education First (First World Conference on Muslim Education on Muslim Education) organized by King Abdul Aziz university in 1977, has not made a clear formulation of the definition of education according to Islam. In the "recommendation" of the Conference, the participants just make a conclusion that the understanding of education according to Islam is "the whole notion embodied in the term study groups, tarbiyah, and ta'dib" (Tafsir, 1994: 28).

The opinion in accordance with the opinion of Langgulung (2000: 3) that in Arabic there are some terms that can be used in the sense that during informal education means teaching, narrower than education; tarbiyah more widely can be used for animals and plants; ta'dib more appropriately used for human education because it can include ta'lim and tarbiyah.

The aouthor analyzed that educational goals of Islamic education can be understood in formulas put forward by experts on Islamic Education. Experts often differ in formulating educational goals. It is based on assumptions which are made emphasis in formulating educational goals. Thus, the core of Islamic education is to worship Allah SWT. Allah says in the Qur'an Surat Adzariat: 56 "And I did not create the jinn and mankind except to worship Me". (Q.S. Adzariyat: 56). 
The formulation of this objective is based on the nature of the creation of jinn and human beings is to worship Allah SWT. Aspects of obedience in worship as a surrender to God be the main emphasis in the formulation of educational goals. Marimba (1986: 39) argues that: Objectives of Islamic Education is the formation of the integrative Muslim personalities between this world and the hereafter ". This understanding requires that the man is no longer as being split in half between the world and the hereafter, rather it is a substance that is in two states at once. Therefore, when humans live in a world completely built by an awareness of the Hereafter.

The formulation of educational goals over philosophical nuance is very strong so it is difficult to find a formula operation in the field of human life, but it is perfectly adequate to provide the basic framework of the objectives of Islamic Education. Islamic education is education through the teachings of the Islamic religion, in the form of guidance and care to the students so that later after the completion of his education he can understand, appreciate and practice the teachings of Islam which has been believed as a whole, and to make the teachings of Islam as a philosophy of life for the safety and welfare of the world and in the hereafter. (Darajat, 2000: 86-89).

Al-Nahlawi (1989: 168) asserts that the education that prioritizes character always equip man with the strength that comes from Allah SWT., Self-confidence which is based on God's help and the reward of heaven, as well as the awareness and the light that comes in the light of Allah. Because morals karimah merupakantujuan operational nature of Islamic education, the Prophet was sent to perfect morals SAW.pun as the Hadith narrated by Ibn Sa'd and Abu Hurairoh which reads: "inama buistu liutamima makarimal morals" Which means I actually sent to enhance ahklak. "While Marsi (1977: 18) found "Achievement of the objectives Islamic education to build human devout worship with abandonment accept God's commands His Messenger SWT.dan followed by amaliyah good quality, is a major goal of education Islam namely the formation of a perfect human being".

Allah says in the Quran surah Al-Isra verse 70 as follows:

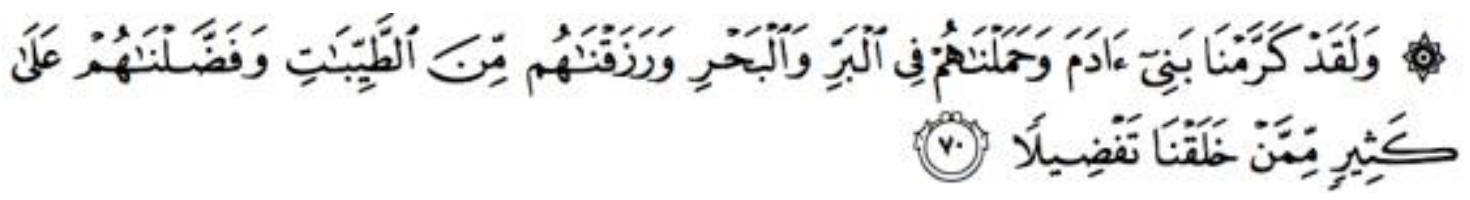

"And indeed We have honored the children of Adam, We carried them on land and at sea, We give them sustenance of good things, and We preferred them with a perfect excess over many We have created". (Q.S. Al-Isra: 70).

From the combination of the two formulations of Islamic education, the more is the philosophy, it can now be understood that Islamic education should be based on the philosophical foundations to be able to keep the consistency and originality, as well as the dose of an operational nature in order to evaluate the process and hasinya as well as the integrity of scientific which must be maintained in the goals of Islamic Education.

The author analyzes that the perfect man as well as the perfect man as communicated by Marimba above, even if no man is perfect, but humans must strive to be a perfect man or a perfect man. The combination of the duties of worship and the role of human caliphs realize their dreams, the perfect man (the perfect man). Humans as the caliph and the servant of God is a unity that enhance the value of humanity as creatures of God to have freedom of choice and creativity which will be accountable before Him at once to confront the demands of nature who put his position to the 
limitations that demands obedience and submission to Allah. human as caliph (representative of God), then God taught the human truths in His creation and through understanding and pengusaannya the laws of truth contained in His creation, then humans can develop concepts and engineering to form a new manifestation in the cultural realm.

As explained in the section above, that "Tahfiz" is Arabic for memorizing, normally, when someone memorized the Quran means he interacts first with reading. Without reading will not succeed memorized. When one reads the Quran means he was communicating with God, seeking the truth, honesty and wisdom in the Qur'an. In this case the presence of Al-Quran as a universal value that applies to all the worlds and civilizations nation. The word value is derived from the Latin or Old French valare namely valoir which means value. Detonatifnya limited sense, valare, valoir, value or values can be interpreted as a price.

From the definition of the value of the above, it can be the common thread that is a reference value and confidence in determining the choice bersifata abstract. The embodiment of the essence and meaning of value can be norms, ethics, regulations, laws, customs, rules a person in living her life. Values are abstract, are behind the facts, bring actions, inherent in one's personal, emerged as the tip of psychological processes, and evolve toward more complex.

In the context of education, the purpose of education is to form the ideal value of the human personality, faith in God, karimah moral, aesthetic and human beings relate to the good relationships that led to a perfect moral (character). Characters (khuluq) is a state of mind. This situation causes the soul to act without thinking or consider deeply. Iniada state of two types. First, the nature and beginning of the character. The second, created by custom and practice. At first, this situation occurs because dipertimbngkan and thought, but then, through constant practice, as a character. The main issues faced in articulating the value of education is the absence of a detailed explanation and firm on the position / status of educational value in the context of national education. However, Muslims can draw the conclusion that the reference to values education and character education is moral education.

In the view of Islam, the integrity of the actual character can not be separated from spiritual formation that will return humans to the substance which is to worship noble, as written in the national education goals: education is a conscious and deliberate effort to create an atmosphere of learning and the learning process so that learners are actively develop the potential for him to have the spiritual power of religion, self-control, personality, intelligence, character, and skills needed him, society, nation and state. Thus, the spiritual power of the students in the birth of the generations who have a certain karimah is spiritual formation in this case is certainly one of them by reading the Quran as the Muslim holy book as well as a communication tool transendetal (communication with God). As one of the ways in an effort to actualize the value, the experts agreed to lift the value in various aspects of life, especially in education, both within the family, school and community so that education becomes an integral value in education in general.

In the beginning, the mission of public education / human values is preparing for a happy and prosperous, while the goal is to create an integrated person = a person as a person and as a citizen (Natawidjaya, 1999: 11). Meaning of public education is to form an integrated human being happy as individuals and citizens.

Currently, the presence of General Education courses is concentrated in the educational value to switch on konsentari character, basically have a common achievement of the moral state of welldeveloped, directed so life becomes meaningful. That is, in the perspective of the nation's character 
education becomes a necessity to be able to answer the various problems in the society, nation and state. Aristotle states that a person who either do not just have one virtue, attitude and behavior of the person is moralita guide in all things. Hersh, et.al., (Budimansyah. 2011).

The kindeness must emanate from their speech, attitude, behavior or if they borrow concepts Thomas Lickona in Budimansyah (2010: 38) is the harmony between moral knowing, moral feeling, and moral action in the sense that a person of character that has a good mind (thinking good), had a good feeling (feeling good), and well behaved (good acting).

Most philosophers assume that human nature is to educate pet (animal educandum). Human nature is powered by nature more known in the history of thought of Western Europe as homo sapiens (human knowing and endowed with reason), homo ludens (man tinkering), homo Recens (man who makes history), homo faber (man technical using tools), homo simbolicum (men who know language symbols), homo concors (human life balanced between himself and others and society), homo economicus (man as a creature of the economy), and animal rational ( rational animal) (Kartono in Mulyana, 2004: 125). In addition, there are also those who think THAT human essence lies precisely in his spiritual spirit in a relationship with his god. According to this view the most essential is a religious man.

\section{B. METHODS}

This research method is done by qualitative phenomenological approach. Phenomenological approach that I use dual focus leads to the observation, namely: 1) what appears in that observation means that all activities are the object of study. 2) what is directly given (given) the experience was directly present (present) for those who experience (neoma). The steps of the phenomenological approach consist of two steps: epoche suspend data or refrain from taking a decision. Ideation is to find the essence of reality Tahfīz Koran activities targeted reduction observation object.

\section{RESULTS AND DISCUSSIONS}

Public education as summary of Values (formation of human identity as individual beings, social, as well as the servant of Allah). At the time of birth, humans have been equipped with a set of potential which includes sensory awareness, sense of awareness, and awareness of spiritual / spiritual (Raharjo in Sauri, 2010: 35). In other words, the potential embodied in the taxonomy of cognitive, affective and psychomotor must be developed to achieve higher goals that perfect man. Target Public Education is "fully human form or human intact". It is thus clear that the Education Value is very active role in realizing the goals and objectives of education.

Pondok Pesantren Persatuan Islam in Karangpawitan as a formal educational institution under the guidance of the Ministry of Religion has a very strong position because it is shaded by a large community organization.

Pondok Pesantren MTs in it gathered educator's undergraduate and graduates, but about $50 \%$ of teachers are concerned not with their respective fields. As teachers' ER, a graduate political ubuntu but teaching social studies and as a curriculum also does not have a four year (legality as a teacher), it of course becomes defective administration and all profesionalan, both teachers of general subjects and subject teachers of religious field is not yet fully professional. In observation of the author, does not give priority boarding majors matches teachers with the material being taught, but the assessed skill in educating students to be perfect man. Pondok Pesantren MTs as formal institutions supervised by the ministry of religion should be able to demonstrate as an institution that 
has a characteristic and uniqueness. Who not only excel in the field of scientific knowledge only religious but general should really be applied so that the graduates are able beradaftasi with the things the world is able to filter the flow of global information vulnerable undermine faith, morals even though jurisprudence.

Geographically Pondok Pesantren Persatuan Islam can be quite strategic, because it can be passed by the main line is the city transportation department and Wanaraja Cibatu. It really is a supporter of capital in order to receive that many students in accordance with the capacity of facilities owned. As more and more students, there will be tough competition and high spirits can cause the child to improve his performance.

Judging from the vision and mission boarding school MTs is good, but need great effort to be able to run. Since it was to be confronted with various problems, both the issue of funding the development of education, preparation of human resources professionals who have been certified and scheduling of teaching and learning that leads to vision and mission.

The issue of funds for the boarding school not too used, as constraints are quite heavy. What is important is the teaching and learning activities must be continued and permanent teaching staff noticed welfare. Obstacles lie in human resources existing teaching not in accordance with the disciplines it has, so that rules can not be said to be professional. For example, the History Teacher held by teachers who graduate from political scholar and holds the curriculum, teachers equivalent to high school graduates Muallimin still perform activities of teaching, whereas in the rule that an educator or teacher is minimal degree (S1).

The setting for teaching and learning activities and hours of formal mulok already organized well, but in learning activities so that there are still weaknesses in the development of talents and interests of students to be channeled to the point to be addressed in the implementation.

The organizational structure of the school has been neatly but there must be repaired. As the chain of command and lines kondinasi, chairman example PC (Branch Exactly command line to the principal). Branch of Islamic unity and institutions of education are two different institutions so that the line of command structure but no coordination. Then there are different istilahpun with a term commonly used today as kesantrian field, the field of curriculum and public relations fields, should be changed to the term Vice Principal (PKS). Facilities and infrastructure look presentable in place each, but there are still some to be completed such as computer labs, science laboratories and language labs, even toilet teachers and students look clean because there are employees who clean every day except Thursday, the students clean the classroom, dormitories and mosques along with toilet jointly considering the usual Friday held Friday prayer.

Achievements of the race or the championship, the authors think it is quite good for MTs level, because it is evident from the testimony of teachers and principals that "at boarding schools often become a champion in the field of calligraphy and other race". It can not be proved physically because in 2005 their lost trophies and two computers by robbing and damaging other facilities even though the document. There is one advantage possessed by Pondok Pesantren is not owned by any other body that development activities morals emphasis on memorizing the Koran that I researched today. The name Al-Quran Tahfiż activity is an activity that focuses students to memorize the corresponding ability of students, but in addition, it is also given an understanding of what is contained in the Koran that they had memorized. The term Tahfīz Al-Quran is the term used is not contained in any reference. Because there and many references are Tazkiyatu An-nafs. Still, it does become a problem because the substance is positive and noble activity in order to maintain 
and restore the sanctity of the human to the substance, namely Al-Quran and As-Sunna. The targets studied are based on objectives, materials, processes, and evaluation of activities Tahfiž Quran hereinafter author discussed below is based on the findings in the field.

As well as Al-Ghazali, he provides the criteria against morals. Namely, that morality should be settled in the spirit and deeds that come easily without the need for prior research. Ethical philosophy of life figures who first declared that morals are "state of the soul that causes people to act without thinking first." He was not rational, or boost appetite. (Maskawaih, 1985: 56). The criteria used al-Ghazali also been introduced enumerated by Ibn Maskawaih. Part character according to lbn Maskawaih (1985: 46-49) is; wisdom (that comes from science), simplicity, daring and generosity and justice. All these elements are balanced (balance / wasath).

In the perspective of ethical philosophy from Aristotle to modern Greece, along with other factors that justice becomes the criterion is also used Kohlberg philosopher, John Dewey and Emile Durkheim. Kohlberg (1995: 32-35) states that this justice will be the basic norms of morality of modern civilized society. According to al-Ghazali (2003; 72-73). There are two ways of educating morals, namely; First, familiarize mujahadah and practice with righteous deeds. Second, the act was done in repeated. It also reached by the first, for the gifts of divine and sempumanya fitrah (events), so lust-lust and anger was made straight, obedient to reason and religion. Then be a man of knowledge $(\bar{a} / \mathrm{lim})$ without learning, educated without education, science is also called ladunniah. Second, the morals and riyāọa mujāhada cultivated, namely by bringing themselves to the actions desired by the character. In short, morals change with educational training. al-Ghazali. (2000: 601$602)$.

The purposes of the Tahfiz̧ above activities is a fundamental objective, particularly on the first point of interest for the key of every act is the heart, the liver is a key element in every step and or words. If the liver is dirty, then the behavior and thoughts will give birth to gross misconduct as well, but on the contrary if a clean heart will be seen from the attitude and behavior. It is not wrong to say that the heart is a reflection of a person. As Nurbakhsy (2001: 183) that "a clean heart and glowing in it like there is a light that illuminates, these believers" be able to produce human beings who have spiritual powers that can counteract the negative influence of the environment in which individuals interact. At the junior level or junior age is a time of self-discovery that will inevitably be affected if not redirected.

The above objective in line with the meaning of education listed in the law No. 20 of 2003 on the national education system: "Education is a conscious and deliberate effort to create an atmosphere of learning and the learning process so that learners are actively developing the potential for him to have the spiritual power of religion, self-control, personality, intelligence noble character, and skills needed him, society and the nation". If the educator be fair and just, away from the reprehensible nature, living according to the Qur'an and Sunna, love Rasullullah SAW, then indirectly will be adopted by the student's attitudes and behavior of the teacher. Radiyallahu Anha A'ishah was once asked by a friend about the morals of the Prophet Muhammad, Aisha answered "depraved is Al-Quran". The short answer to the personal and universal as Rasullullah. Education with custom, the meaning of nature is that man created God has a sense of religion, ie the religion of monotheism.

The existence of the Koran Tahfīz activities in institutions help to change behavior. Because of the activities of memorizing Al-Quran, the students always keep their rote by maintaining the attitude and behavior was disgraceful. Evidenced by a student named A class IX, N, class IX, he never played facebook is one of the social networks that is currently much in demand by many. He uses 
this facebook for two hours, it turns out she was memorizing which he had memorized very hard to remember when murojaah. Finally, he decided to undertake activities that would not interfere with memory. This is presumably the penghapal Koran constantly keeping their behaviors or actions of the things that can weaken or even eliminate rote memorizing the Koran. This means that they are not only smart intellectually and emotionally, but also spiritually. If a person's relationship with God good then surely the relationship with a fellow human being will be good too. Within a few months back tasikmalaya city government, ciamis and even governments in the field of education Ministry of Religious Affairs urged to cultivate reading the Quran after maghrib. It is a cursory look strange, why only instructed or urged to read the Quran at sunset only, opinions appear in the people of the two cities, the change of the time of day to night that will affect children's intelligence, especially when reading the Koran or (tadarus) at the time of maghrib.

The foregoing seems in tune with a research turns reading the Qur'an at dusk and after dawn that can increase the intelligence of the brain to $80 \%$, because there is no change from daytime to night and from night kesiang day in addition there are three activities at once, read, see and hear. "There are some things that can cause someone strong recollection or memory. Among them, menyedikitkan eat, familiarize conducting worship night prayer and reading the Koran, looking for Manuscripts". There is no longer upliftment of the memory and provide peace to a person unless read the Koran". Al Qadhi, through a long and serious research on the Great Clinic Florida United States, managed to prove just by listening to reading the verses of the Koran, a Muslim, both those who speak Arabic or not, can feel a huge physiological change. Decreased depression, grief, gain peace of mind, ward off various diseases are common effects of perceived people who became the object of research.

The discovery of a psychiatrist doctor is not haphazard. His research is supported with the help of the latest electronic equipment to detect blood pressure, heart rate, muscle endurance, and skin resistance to the flow of electricity. From the results of a test try he concluded, reading the Koran great influence up to $97 \%$ in the delivery of mental tranquility and healing diseases. (Sayyidario.blogspot.com. 00:20:23 June 2011). In a research report submitted by the Conference of Islamic Medical North America in 1984, is mentioned, the Koran proved able to bring tranquility to $97 \%$ for those who listen. Conclusion The test results reinforced by research published Muhammad Salim Boston University. The object of his research on five volunteers consisting of 3 men and 2 women. The fifth person did not understand Arabic and they were not told that that would diperdengarkannya is the Koran.

Research carried out a total of 210 times is divided into two sessions, ie recite the Quran with reciting Arabic tartil and not from the Koran. In conclusion, respondents get peace of up to $65 \%$ when listening to reading the Koran and get peace, only $35 \%$ when listening to the Arabic language, which is not from the Al Qur'an.

\section{CONCLUSION}

The success of building a national character to foster the spirit to keep the moral values of alkarimah. Tahfizz through the Koran, students are the joint responsibility of the various components of society that must be done continuously, integrated, and systematic with various innovations to achieve a common goal of development or improvement of morals. With the hope that the formation of moral approach and mengahapal reading the Koran can be achieved optimally. If it is not implemented, then the law will not causally harmonious relations among communities because of the emphasis in the education process is not a religious approach. Strong impetus to understand and get used to practice the values of Islam (Quran) on yourself and on every activity of life will help 
accelerate the realization of the community who have a character or good morals. Vice versa is not used to and do not practice the values of the Qur'an, it is far from a life of character akhlakul karimah. Success in internalization moral values of students in school by integrating the values of the Qur'an will have a positive impact on improving achievement, behavior and moral consciousness as a form of personal intelligent and humane society (noble). 


\section{References}

Al-Attas N. (1991). Konsep Pendidikan Islam. Bandung: Mizan.

Al-Nahlawi, A. (2009). Prinsip-prinsip Pendidikan Islam. Bandung: Diponegoro.

Djamarah, S. (2000). Guru dan anak didik dalam interaksi edukatif. Jakarta: Intermasa.

El mubarok, Z. (2008). Membumikan Pendidikan nilai. Bandung: Alfabeta.

Ghozali, (2000). Mutiara Ihya Ulumuddin: Jakarta Mizan.

Gunansyah, G. (2010). Itegrasi Pendidikan Nilai dalam Membangun Karakter Siswa di Sekolah Dasar. [Online]. Available at: http://edukasi.kompasiana.com

Margono, S. (2005). Metodologi Penelitian Pendidikan. Bandung: Rineka Persada.

Marimba, A. (1986). Pengantar Filsafat Pendidikan Islam. Bandung: Rineka Persada.

Maskawaih, Ibn., (1999). Menuju Kesempurnaan Akhlak. Bandung: Mizan.

Mulyana. (1996). Upaya guru dan kepala sekolah dalam membina keimanan dan ketaqwaan islam. Bandung: FPS IKIP Bandung.

Nasir, M. (1991). Tinjauan Akhlak. Surabaya: Al-lkhlas. 
Morals Coaching Through Tahfizh al-Quran in Islamic Junior High School:

A Case Study in PERSIS Islamic Boarding School in Karangpawitan Garut West Java 